\title{
PEMANFAATAN LIMBAH PADAT INDUSTRI KARET REMAH (CRUMB RUBBER) UNTUK PEMBUATAN KOMPOS
}

\section{UTILIZATION OF CRUMB RUBBER INDUSTRY SOLID WASTE FOR MAKING COMPOST}

\author{
Supraptiningsih*, Nursamsi Sarengat \\ Balai Besar Kulit, Karet, dan Plastik, Yogyakarta \\ *E-mail: ningsih1957@yahoo.com
}

Diterima: 20 Februari 2014 Direvisi: 16 Mei 2014 Disetujui: 22 Mei 2014

\begin{abstract}
The objective of the research was to create a compost formula for plant fertilizer. Composts containing 100, 90, 80, 70, 60, and 50 parts of crumb rubber industry solid waste and 10, 20, 30, 40, and 50 parts of bran were prepared. The mixing was done by adding $20 \mathrm{ml}$ of molasses and 20 $\mathrm{ml}$ of EM4. Moisture content was maintained at 40-60\%. The compost was mature in 40 days. The resulting compost was compared to SNI 2803:2010 Solid NPK Fertilizer and Regulation of the Minister of Agriculture No. 70/Permentan/SR-140/10/2011 on Organic Fertilizer. The best compost that met the requirements (except kalium) was the compost with 20 parts of bran, 80, 90, and 100 parts of solid waste. The physical properties of the compost were dark brown similar to the color of the soil, insoluble in water, C/N ratio of 20.74 to 25.44, temperature approximately equal to the ambient, and odorless.
\end{abstract}

Keywords: crumb rubber industry solid waste, bran, $C / N$ ratio

\begin{abstract}
ABSTRAK
Tujuan penelitian adalah membuat formula kompos untuk pupuk tanaman. Variasi dalam pembuatan kompos yaitu jumlah limbah padat industri crumb rubber sebesar 100, 90, 80, 70, 60, dan 50 bagian, serta jumlah bekatul sebesar 10, 20, 30, 40, dan 50 bagian. Pencampuran dilakukan dengan penambahan tetes sebanyak $20 \mathrm{ml}$ dan EM4 sebanyak $20 \mathrm{ml}$. Air ditambahkan sampai campuran mempunyai kelembaban 40-60\%. Kompos matang pada hari ke-40. Hasil pupuk kompos dibandingkan dengan SNI 2803:2010 Pupuk NPK Padat serta Peraturan Menteri Pertanian No:70/ Permentan/SR-140/10/2011 tentang Pupuk Organik. Kompos hasil penelitian terbaik dan memenuhi persyaratan (kecuali kalium) adalah kompos dengan formulasi bekatul 20 bagian dan limbah padat crumb rubber 80, 90, dan 100 bagian. Kompos tersebut memiliki sifat fisika antara lain berwarna coklat tua agak hitam mirip dengan warna tanah, tidak larut dalam air, $\mathrm{C} / \mathrm{N}$ rasio sebesar 20,7425,44, suhu kurang lebih sama dengan suhu lingkungan, dan tidak berbau.
\end{abstract}

Kata kunci: limbah padat industri crumb rubber, bekatul, rasio $\mathrm{C} / \mathrm{N}$

\section{PENDAHULUAN}

Karet remah (crumb rubber) adalah produk karet alam yang merupakan produk setengah jadi dan pengolahannya melalui tahap peremahan. Kebersihan karet yang dihasilkan dari proses pengolahan crumb rubber tergantung dari kualitas bahan baku yang dipakai. Bahan baku karet sebagian besar didapatkan dari perkebunan rakyat yang kurang bersih, dan biasanya perusahaan tidak terlalu ketat dalam melakukan penyortiran kualitas bahan baku yang masuk. Setiap pengolahan $100 \mathrm{~kg}$ lateks akan menghasilkan lebih kurang $85 \%$ karet bersih, $10 \%$ air dan 3-5\% tatal (Mutiara dan 
Hakimi, 2012).

Sebelum mengalami proses peremahan, bahan olah karet (bokar) dipotong-potong menggunakan mesin breaker dan dicuci untuk menghilangkan kotoran yang tercampur dalam bokar dengan mesin Hammermill. Setelah itu diproses menjadi blanket, yaitu berupa lembaran dengan panjang 7-9 $\mathrm{m}$ dan tebal 5-7 $\mathrm{mm}$. Pada proses peremahan inilah muncul adanya limbah padat yang berasal dari saat pengambilan getah karet di pohon berupa tatal-tatal kayu, kulit kayu, dan daun-daun yang tercampur saat penyadapan. Disamping limbah-limbah yang tercampur dengan tidak sengaja, ada pula limbah padat yang sengaja dicampurkan oleh petani karet untuk menambah berat, biasanya berupa tanah atau pasir.

Ketersediaan limbah padat crumb rubber di Indonesia cukup banyak (Direktorat Jenderal Perkebunan, 2010). Limbah tersebut selama ini belum ditangani secara efektif. Limbah hanya ditumpuk di lokasi pabrik dan kadang-kadang diminta oleh penduduk untuk pupuk tanaman dan untuk landfill. Apabila tidak ada permintaan dari penduduk, maka dibiarkan menggunung di lokasi pabrik. Pemanfaatan limbah crumb rubber (tatal) oleh industri adalah sebagai media tanaman $(18,3 \%)$ untuk tanaman yang ada di halaman pabrik (seperti yang dilakukan oleh pabrik karet di Padang) (Mutiara dan Hakimi, 2012). Pemanfaatan lain sebagai media tanam oleh pengusaha tanaman hias yang hanya membutuhkan jumlah sedikit dari tatal yang dihasilkan setiap kali produksi crumb rubber. Selain itu tatal juga dimanfaatkan sebagai timbunan jalan (10\%) dan sebagian besar industri $(71,7 \%)$ belum memanfaatkan tatal. Limbah tersebut mengandung unsur N, P, dan $\mathrm{K}$ yang cukup tinggi. Pada penelitian ini limbah crumb rubber akan dibuat kompos, sehingga diharapkan dapat menaikkan nilai jual limbah padat tersebut.

Kompos adalah hasil penguraian parsial/ tidak lengkap dari campuran bahan-bahan organik yang dapat dipercepat secara artifisial oleh berbagai macam mikroba dalam kondisi lingkungan yang hangat, lembab, dan aerobik atau anaerobik. Pengomposan adalah proses dimana bahan organik mengalami penguraian secara biologis, khususnya oleh mikroba- mikroba yang memanfaatkan bahan organik sebagai sumber energi. Membuat kompos adalah mengatur dan mengontrol proses alami tersebut agar kompos dapat terbentuk lebih cepat. Proses ini meliputi pembuatan campuran bahan yang seimbang, pemberian air yang cukup, pengaturan aerasi, dan penambahan aktivator pengomposan. Aktivator pengomposan yang sudah banyak beredar antara lain: Promi (Promoting Microbes), OrgaDec, SuperDec, ActiComp, BioPos, EM4, Green Phosko Organic Decomposer dan Superfarm (Effective Microorganism) atau menggunakan cacing guna mendapatkan kompos (vermikompos). Setiap aktivator memiliki keunggulan sendirisendiri (Kaosol and Wandee, 2009).

Pengomposan secara aerobik paling banyak digunakan, karena mudah dan murah untuk dilakukan, serta tidak membutuhkan kontrol proses yang terlalu sulit. Dekomposisi bahan dilakukan oleh mikroorganisme di dalam bahan itu sendiri dengan bantuan udara. Bahan baku pengomposan adalah semua material yang mengandung karbon dan nitrogen. Pada dasarnya semua bahan-bahan organik padat dapat dikomposkan, misalnya: kotoran hewan ternak, sampah rumah tangga dan perkotaan, limbah media jamur (Wei et al., 2014), lumpur pengolahan air limbah (Xue and Huang, 2013), dan limbah agro industri (Ting et al., 2013; Raj and Antil, 2011). Proses pengomposan tergantung pada karakteristik bahan yang dikomposkan, aktivator pengomposan yang dipergunakan, dan metode pengomposan yang dilakukan. Faktor-faktor yang mempengaruhi proses pengomposan antara lain rasio $\mathrm{C} / \mathrm{N}$, aerasi, kelembaban, suhu, $\mathrm{pH}$, kandungan hara, ukuran partikel, dan porositas (Li et al., 2013; Bernal et al., 2009).

Kelembaban (moisture content) memegang peranan yang sangat penting dalam proses metabolisme mikroba dan secara tidak langsung berpengaruh pada penyediaan oksigen. Mikroorganisme dapat memanfaatkan bahan organik apabila bahan organik tersebut larut di dalam air. Kelembaban 40-60 \% adalah kisaran optimum untuk metabolisme mikroba. Apabila kelembaban di bawah $40 \%$, aktivitas mikroba akan mengalami penurunan dan akan lebih rendah lagi pada kelembaban 15\%. Apabila 
kelembaban lebih besar dari $60 \%$, hara akan tercuci, volume udara berkurang, akibatnya aktivitas mikroba akan menurun dan akan terjadi fermentasi anaerobik yang menimbulkan bau tidak sedap.

Proses pengomposan dapat terjadi pada kisaran $\mathrm{pH}$ yang lebar. $\mathrm{pH}$ yang optimum untuk proses pengomposan berkisar antara 6,5-7,5. $\mathrm{pH}$ kotoran ternak umumnya berkisar antara 6,8-7,4. Proses pengomposan sendiri akan menyebabkan perubahan pada bahan organik dan $\mathrm{pH}$ bahan itu sendiri. Sebagai contoh, proses pelepasan asam, secara temporer atau lokal, akan menyebabkan penurunan $\mathrm{pH}$ (pengasaman), sedangkan produksi amonia dari senyawa-senyawa yang mengandung nitrogen akan meningkatkan $\mathrm{pH}$ pada fase-fase awal pengomposan. $\mathrm{pH}$ kompos yang sudah matang biasanya mendekati netral. Kandungan $\mathrm{P}$ dan $\mathrm{K}$ juga penting dalam proses pengomposan dan biasanya terdapat di dalam kompos-kompos dari peternakan. Hara ini akan dimanfaatkan oleh mikroba selama proses pengomposan (Iqbal et al., 2010).

Beberapa bahan organik mungkin mengandung logam berat seperti $\mathrm{Mg}, \mathrm{Cu}, \mathrm{Zn}$, Nickel, Cr yang merupakan bahan berbahaya bagi kehidupan mikroba (Handayani, 2009). Organisme yang banyak dipergunakan adalah mikroba, baik bakteri, aktinomisetes, maupun kapang/cendawan.

Tujuan penelitian adalah membuat formula kompos untuk pupuk tanaman. Hasil pupuk kompos dibandingkan dengan SNI 2803:2010 Pupuk NPK Padat dan Peraturan Menteri Pertanian No:70/Permentan/SR. 140/10/2011 tentang Pupuk Organik. Produk kompos yang dapat digunakan untuk pupuk tanaman.

\section{BAHAN DAN METODE Bahan Penelitian}

Bahan baku yang digunakan pada penelitian ini adalah limbah padat crumb rubber yang diperoleh dari PT Raberindo Pratama berlokasi di Dsn. Nglorok, Kec. Boja, Kab. Kendal, Jawa Tengah. Limbah padat diambil pada tahap proses pencucian bokar di alat Hammermill dan pada tahapan penyaringan pembuangan limbah cair sebelum masuk ke unit pengolah limbah (rubber trap). Keduanya dicampur dengan jumlah bagian yang sama, dan baru diberi perlakuan sesuai desain penelitian yang telah ditetapkan.

Bahan penolong yang digunakan untuk proses pengolahan limbah menjadi kompos adalah EM4 sebagai aktivator, bekatul dan gula pasir(tetes) sebagai sumberenergi bagi mikrobia, serta air untuk menjaga kelembaban kompos. EM4 mengandung berbagai jenis mikroba, namun yang menonjol yaitu bakteri lactobacille $s p$, streptomyces sp, ragi, actinomycetes dan bakteri fotosintetik. EM4 diberikan secara langsung untuk menambah hara rendah. Hasil fermentasi dengan EM4 disebut bokashi (Mayer et al., 2010).

\section{Peralatan Penelitian}

Peralatan yang dibutuhkan dalam pengomposan secara aerobik terdiri dari peralatan untuk penanganan bahan dan peralatan perlindungan keselamatan dan kesehatan bagi pekerja. Berikut disajikan peralatan yang digunakan: Keranjang sampah (terbuat dari plastik, diameter $15 \mathrm{~cm}$, tinggi $50 \mathrm{~cm}$ dapat menahan bahan $5 \mathrm{~kg}$ ), sekop kecil, saringan/ ayakan, termometer, timbangan, sarung tangan, dan masker.

\section{Metode Penelitian}

Penelitian dilakukan dengan membuat kompos skala laboratorium. Dilakukan variasi pada jumlah limbah dan jumlah bekatul. Bahan baku limbah padat crumb rubber ditimbang sesuai masing-masing formulasi. Pencampuran dilakukan dengan penambahan bekatul sesuai formulasi, tetes sebanyak $20 \mathrm{ml}$, dan EM4 sebanyak $20 \mathrm{ml}$. Air ditambahkan sampai campuran mempunyai kelembaban 40-60\%. Larutan gula (tetes) dibuat dengan melarutkan $500 \mathrm{~g}$ gula pasir dalam $500 \mathrm{ml}$ air. Proses pembalikan dan penyiraman dilakukan seminggu 2 kali. Pengecekan suhu dilakukan setiap hari pada 10 hari pertama, selanjutnya pengecekan suhu 1 kali seminggu. Kompos matang pada hari ke-40.

Penelitian ini menggunakan dosis limbah padat karet remah $100 ; 90 ; 80 ; 70 ; 60$; dan 50 bagian, sedangkan dosis bekatul adalah 10; 20; 30; 40; dan 50 bagian. Matriks desain penelitian terlihat pada Tabel 1.

Disamping formulasi di atas, juga dibuat blanko untuk kontrol. Blanko dibuat dengan 
Tabel 1. Desain penelitian dengan variasi limbah padat industri crumb rubber dan bekatul

\begin{tabular}{ccccccc}
\hline \multirow{2}{*}{$\begin{array}{c}\text { Bekatul } \\
\text { (bagian) }\end{array}$} & 100 & 90 & 80 & 70 & 60 & 50 \\
\cline { 2 - 7 } & $\left(\mathrm{b}_{1}\right)$ & $\left(\mathrm{b}_{2}\right)$ & $\left(\mathrm{b}_{3}\right)$ & $\left(\mathrm{b}_{4}\right)$ & $\left(\mathrm{b}_{5}\right)$ & $\left(\mathrm{b}_{6}\right)$ \\
\hline $10\left(\mathrm{a}_{1}\right)$ & $\left(\mathrm{a}_{1} \mathrm{~b}_{1}\right)$ & $\left(\mathrm{a}_{1} \mathrm{~b}_{2}\right)$ & $\left(\mathrm{a}_{1} \mathrm{~b}_{3}\right)$ & $\left(\mathrm{a}_{1} \mathrm{~b}_{4}\right)$ & $\left(\mathrm{a}_{1} \mathrm{~b}_{5}\right)$ & $\left(\mathrm{a}_{1} \mathrm{~b}_{6}\right)$ \\
$20\left(\mathrm{a}_{2}\right)$ & $\left(\mathrm{a}_{2} \mathrm{~b}_{1}\right)$ & $\left(\mathrm{a}_{2} \mathrm{~b}_{2}\right)$ & $\left(\mathrm{a}_{2} \mathrm{~b}_{3}\right)$ & $\left(\mathrm{a}_{2} \mathrm{~b}_{4}\right)$ & $\left(\mathrm{a}_{2} \mathrm{~b}_{5}\right)$ & $\left(\mathrm{a}_{2} \mathrm{~b}_{6}\right)$ \\
$30\left(\mathrm{a}_{3}\right)$ & $\left(\mathrm{a}_{3} \mathrm{~b}_{1}\right)$ & $\left(\mathrm{a}_{3} \mathrm{~b}_{2}\right)$ & $\left(\mathrm{a}_{3} \mathrm{~b}_{3}\right)$ & $\left(\mathrm{a}_{3} \mathrm{~b}_{4}\right)$ & $\left(\mathrm{a}_{3} \mathrm{~b}_{5}\right)$ & $\left(\mathrm{a}_{3} \mathrm{~b}_{6}\right)$ \\
$40\left(\mathrm{a}_{4}\right)$ & $\left(\mathrm{a}_{4} \mathrm{~b}_{1}\right)$ & $\left(\mathrm{a}_{4} \mathrm{~b}_{2}\right)$ & $\left(\mathrm{a}_{4} \mathrm{~b}_{3}\right)$ & $\left(\mathrm{a}_{4} \mathrm{~b}_{4}\right)$ & $\left(\mathrm{a}_{4} \mathrm{~b}_{5}\right)$ & $\left(\mathrm{a}_{4} \mathrm{~b}_{6}\right)$ \\
$50\left(\mathrm{a}_{5}\right)$ & $\left(\mathrm{a}_{5} \mathrm{~b}_{1}\right)$ & $\left(\mathrm{a}_{5} \mathrm{~b}_{2}\right)$ & $\left(\mathrm{a}_{5} \mathrm{~b}_{3}\right)$ & $\left(\mathrm{a}_{5} \mathrm{~b}_{4}\right)$ & $\left(\mathrm{a}_{5} \mathrm{~b}_{5}\right)$ & $\left(\mathrm{a}_{5} \mathrm{~b}_{6}\right)$ \\
\hline
\end{tabular}

formulasi tanpabekatul,yangberarti penggunaan limbah padat crumb rubber 100 bagian. Kompos hasil penelitian dilakukan pengujian sifat fisis dan uji unsur-unsur kimia sesuai SNI 2803: 2010 (BSN, 2010) dan Peraturan Menteri Pertanian No:70/Permentan/SR. 140/10/2011 (Menteri Pertanian, 2011).

Data hasil uji sifat fisis dianalisis statistik dengan menggunakan metode factorial desain. Hasil perhitungan statistik berupa tabel Anova yang digunakan sebagai acuan pembahasan untuk dapat mengetahui pengaruh jumlah limbah padat crumb rubber dan pengaruh bekatul terhadap sifat fisis kompos.

\section{HASIL DAN PEMBAHASAN}

Bahan baku pembuatan kompos yaitu limbah padat industri crumb rubber diuji kandungan $\mathrm{N}, \mathrm{P}, \mathrm{K}, \mathrm{S}, \mathrm{C}$, dan rasio $\mathrm{C} / \mathrm{N}$. Hasil pengujian tercantum pada Tabel 2.

Selama proses pengomposan diamati uji rasio $\mathrm{C} / \mathrm{N}$ pada minggu ke-2 dan minggu ke-4 untuk melihat aktivitas mikrobia. Hasil pengamatan rasio $\mathrm{C} / \mathrm{N}$ dilaporkan pada Gambar 1.

Kompos hasil penelitian diuji sesuai SNI 2803:2010 Pupuk NPK Padat dan Peraturan Menteri Pertanian No:70/Permentan/SR. 140/10/2011 tentang Pupuk Organik. Hasil uji kompos dapat dilihat pada Tabel 3.

Hasil uji rasio $\mathrm{C} / \mathrm{N}$ menunjukkan kisaran 16,85-36,43 untuk semua formulasi kompos yang dibuat. Pada SNI 2803:2010 Pupuk NPK Padat tidak ada persyaratan untuk angka rasio $\mathrm{C} / \mathrm{N}$, sedangkan pada Peraturan Menteri Pertanian No 70/Permentan/SR 140/10/2011 tanggal 25 Oktober 2011 untuk pupuk organik
Tabel 2. Hasil uji limbah padat industri crumb rubber

\begin{tabular}{ccc}
\hline No & Parameter Uji & Hasil \\
\hline 1 & Kalium (K) & $0,29 \%$ \\
2 & Fosfor (P) & $0,18 \%$ \\
3 & Bahan organik & $72,22 \%$ \\
4 & Karbon (C) & $41,88 \%$ \\
5 & Nitrogen (N) & $1,28 \%$ \\
6 & Rasio C/N & 32,72 \\
\hline
\end{tabular}

padat mensyaratkan angka 15-25. Hasil uji rasio $\mathrm{C} / \mathrm{N}$ terkecil dicapai oleh kompos dengan bekatul 10 bagian dan limbah padat 90 bagian, yaitu sebesar 16,85 . Hasil uji rasio $\mathrm{C} / \mathrm{N}$ terbesar dicapai oleh kompos dengan bekatul 40 bagian dan limbah padat 60 bagian. Hasil uji menunjukkan kecenderungan makin banyak limbah padat crumb rubber yang digunakan, makin tinggi angka rasionya. Rasio $\mathrm{C} / \mathrm{N}$ yang sesuai persyaratan menunjukkan proses pengomposan berjalan baik. Rasio $\mathrm{C} / \mathrm{N}$ blanko menunjukkan angka 25,89 pada minggu ke 4 .

Rasio $\mathrm{C} / \mathrm{N}$ yang efektif untuk proses pengomposan berkisar antara 30:1 hingga 40:1. Mikroba memecah senyawa $\mathrm{C}$ sebagai sumber energi dan menggunakan $\mathrm{N}$ untuk sintesis protein. Pada rasio $\mathrm{C} / \mathrm{N}$ di antara $30 \mathrm{~s} / \mathrm{d} 40$ mikroba mendapatkan cukup $\mathrm{C}$ untuk energi dan $\mathrm{N}$ untuk sintesis protein. Apabila rasio $\mathrm{C} / \mathrm{N}$ terlalu tinggi, mikroba akan kekurangan $\mathrm{N}$ untuk sintesis protein sehingga dekomposisi berjalan lambat. Hasil penelitian menunjukkan rasio $\mathrm{C} / \mathrm{N}$ berkisar antara 16,85-36,48. Kompos yang menunjukkan rasio $\mathrm{C} / \mathrm{N}$ efektif adalah kompos dengan kode $a_{2} b_{1}, a_{2} b_{2}$, dan $a_{3} b_{3}$ yaitu kompos dengan pemakaian bekatul 20 bagian dan limbah 


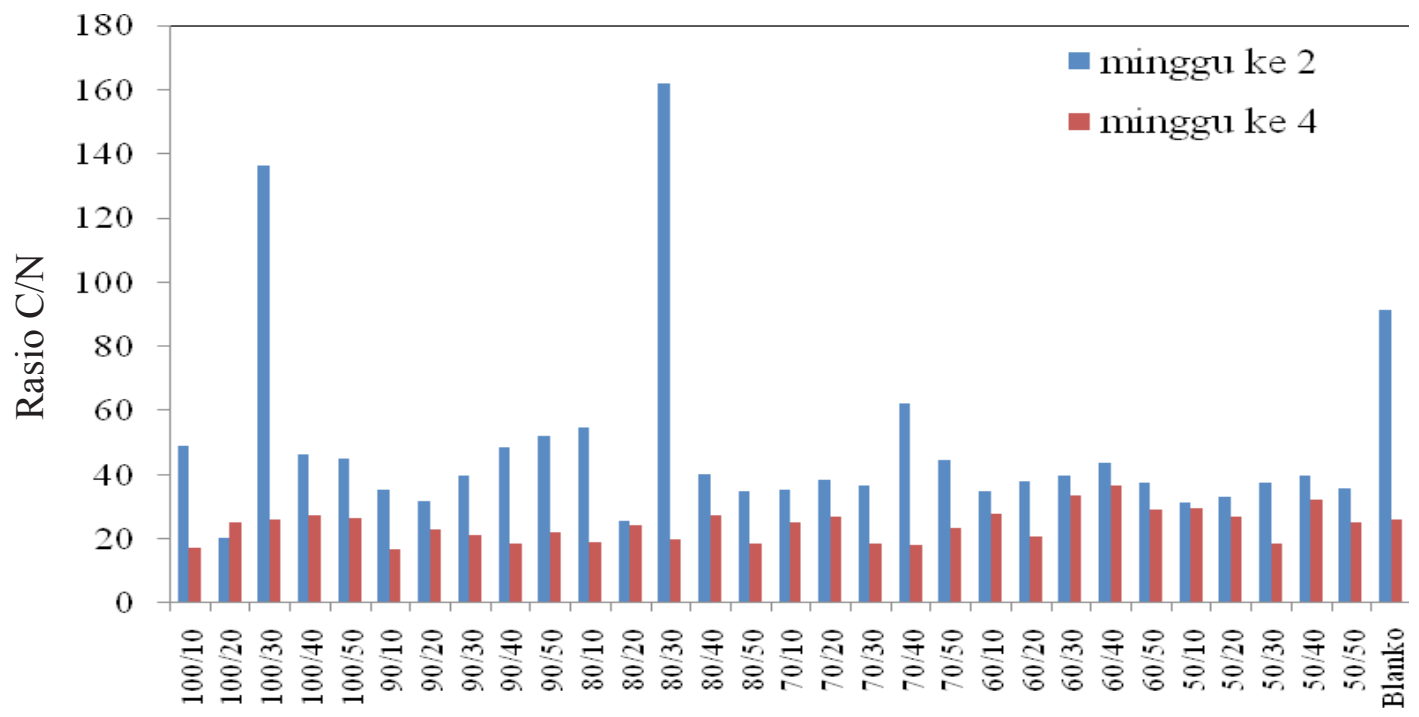

Limbah crumb rubber/bekatul

Gambar 1. Hasil uji rasio $\mathrm{C} / \mathrm{N}$ pada proses pengomposan dengan variasi rasio limbah crumb rubber/ bekatul

Tabel 3: Hasil Uji Kompos Hasil Penelitian dibandingkan SNI NPK Padat 2803-2010

\begin{tabular}{lcccc}
\hline \multicolumn{1}{c}{ Parameter Uji } & \multicolumn{3}{c}{ Hasil Uji } & Persyaratan \\
\cline { 2 - 4 } & $100 / 20$ & $90 / 20$ & $80 / 20$ & SNI 2803:2010 \\
\hline Nitrogen, \% b/b & 9,8 & 13,7 & 12,0 & Min. 8 \\
Fosfor, \% b/b & 4,1 & 11,1 & 8,0 & Min. 8 \\
Kalium, \% b/b & 2,7 & 3,1 & 3,8 & Min. 8 \\
Jumlah kadar NPK, \% b/b & 16,6 & 27,9 & 23,8 & Min. 8 \\
Kadar air, \% b/b & 5,04 & 4,10 & 3,75 & Maks. 3 \\
Cemaran logam & & & & \\
$\quad$ - Raksa (Hg), ppm & $<0,002$ & $<0,002$ & $<0,002$ & Maks. 10 \\
$\quad$ - Kadmium (Cd), ppm & $<0,01$ & $<0,01$ & $<0,01$ & Maks. 100 \\
$\quad$ - Timbal (Pb), ppm & -- & -- & -- & Maks. 500 \\
Arsen, ppm & $<0,005$ & $<0,005$ & $<0,005$ & Maks. 100 \\
\hline
\end{tabular}

padat crumb rubber 100, 90, dan 80 bagian. Masalah utama pengomposan adalah pada rasio $\mathrm{C} / \mathrm{N}$ yang tinggi, terutama jika bahan utamanya mengandung kadar kayu tinggi (tatal, sisa gergajian kayu, ranting, ampas tebu, dsb). Guna menurunkan rasio $\mathrm{C} / \mathrm{N}$ diperlukan perlakuan khusus,yaitu menambahkan mikroorganisme selulotik (Haddadin et al., 2009) atau dengan menambahkan kotoran hewan karena kotoran hewan mengandung banyak senyawa nitrogen.

Hasil uji N,P,K dan kadar air dibandingkan dengan SNI 2803:2010 Pupuk NPK Padat. Formulasi yang memenuhi persyaratan standard tersebut (kecuali kalium) adalah kompos yang dibuat dengan bekatul 20 bagian, dan limbah 100 bagian, 90 bagian, serta 80 bagian. Kenampakan kompos tersebut telah matang. Pengamatan suhu menunjukkan kenaikan sampai pada hari ke-10 dan minggu ke-2 mulai turun.. Ada hubungan langsung antara peningkatan suhu dengan konsumsi oksigen. Makin tinggi temperatur makin banyak konsumsi oksigen dan akan makin mempercepat proses dekomposisi. Suhu yang berkisar antara $30-60^{\circ} \mathrm{C}$ menunjukkan aktivitas pengomposan yang cepat. Suhu yang lebih tinggi dari $50^{\circ} \mathrm{C}$ akan membunuh mikroba mesofilik dan hanya mikroba termofilik saja yang akan tetap hidup (Li et al., 2013).

Tabel 4 menunjukkan sifat atau kualitas kompos yang dihasilkan. Ditinjau dari sifat 
Tabel 4. Hasil Uji Kompos Hasil Penelitian dibandingkan Peraturan Menteri Pertanian No: 70/Permentan/ SR-140/10/2011 tentang Pupuk Organik.

\begin{tabular}{|c|c|c|c|c|}
\hline \multirow{2}{*}{ Parameter Uji } & \multicolumn{3}{|c|}{ Hasil Uji } & \multirow{2}{*}{$\begin{array}{c}\text { Persyaratan Permentan } \\
\text { No: } 70 / \text { Permentan/SR- } \\
\text { 140/10/2011 }\end{array}$} \\
\hline & $100 / 20$ & $90 / 20$ & $80 / 20$ & \\
\hline Nitrogen, $\% \mathrm{~b} / \mathrm{b}$ kering & 9,8 & 13,7 & 12,0 & Tidak dipersyaratkan \\
\hline Fosfor $\% \mathrm{~b} / \mathrm{b}$ kering & 4,1 & 11,1 & 8,0 & Tidak dipersyaratkan \\
\hline Kalium, \% b/b kering & 2,7 & 3,1 & 3,8 & Tidak dipersyaratkan \\
\hline $\begin{array}{l}\text { Jumlah kadar NPK (hara makro), } \\
\% \text { b/b kering }\end{array}$ & 16,6 & 27,9 & 23,8 & Min. 4 \\
\hline Kadar air, $\%$ b/b kering & 5,04 & 4,10 & 3,75 & $15-25$ \\
\hline \multicolumn{5}{|l|}{ Cemaran logam } \\
\hline - $\quad$ Raksa (Hg), ppm & $<0,002$ & $<0,002$ & $<0,002$ & Maks. 1 \\
\hline - $\quad \operatorname{Kadmium}(\mathrm{Cd}), \mathrm{ppm}$ & $<0,01$ & $<0,01$ & $<0,01$ & Maks. 2 \\
\hline - $\quad$ Timbal $(\mathrm{Pb}), \mathrm{ppm}$ & -- & -- & -- & Maks. 50 \\
\hline Arsen, ppm & $<0,005$ & $<0,005$ & $<0,005$ & Maks. 10 \\
\hline C-organik, $\% \mathrm{~b} / \mathrm{b}$ kering & 27,58 & 24,95 & 26,25 & Min 15 \\
\hline Rasio C/N & 25,30 & 23,10 & 24,31 & $15-25$ \\
\hline $\begin{array}{l}\text { Bahan ikutan (plastik, kaca, } \\
\text { kerikil) }\end{array}$ & -- & -- & -- & Maks. 2 \\
\hline $\mathrm{pH}$ & 7 & 7 & 7 & $4-9$ \\
\hline
\end{tabular}

kimia, kompos ini mempunyai kondisi $\mathrm{pH} 7$. Faktor $\mathrm{pH}$ sangat menentukan mudah tidaknya unsur-unsur hara diserap oleh tanaman. Pada umumnya unsur hara mudah diserap akar tanaman pada $\mathrm{pH}$ netral, karena pada $\mathrm{pH}$ tersebut kebanyakan unsur hara mudah larut dalam air. Nisbah C/N 23,10-25,3 termasuk memenuhi persyaratan Permentan No: 70/Permentan/SR140/10/2011.

Hasil perhitungan statistik menggunakan ANOVA menunjukkan bahwa penambahan jumlah limbah padat berpengaruh nyata terhadap nilai rasio $\mathrm{C} / \mathrm{N}$. Makin banyak limbah yang ditambahkan, maka nilai rasio $\mathrm{C} / \mathrm{N}$ meningkat. Hal ini sesuai dengan hasil uji limbah padat sebelum diolah menjadi kompos, menunjukkan nilai rasio $\mathrm{C} / \mathrm{N}$ yang cukup tinggi yaitu sebesar 32,72. Pengolahan limbah menunjukkan penurunan nilai rasio $\mathrm{C} / \mathrm{N}$ secara nyata.

\section{KESIMPULAN}

Kompos terbaik dan memenuhi persyaratan SNI 2803:2010 Pupuk NPK Padat (kecuali
Kalium) serta memenuhi Peraturan Menteri Pertanian No: 70/Permentan/SR-140/10/2011 tentang Pupuk Organik adalah kompos dengan formulasi bekatul 20 bagian dan limbah padat crumb rubber 100 bagian, 90 bagian dan 80 bagian. Kompos tersebut memiliki ciri antara lain: berwarna coklat tua agak hitam mirip dengan warna tanah, tidak larut dalam air, rasio $\mathrm{C} / \mathrm{N}$ sebesar 25,30; 23,10; dan 24,31, suhu kurang lebih sama dengan suhu lingkungan, dan tidak berbau.

\section{UCAPAN TERIMA KASIH}

Ucapan terima kasih disampaikan kepada Balai Besar Kulit, Karet, dan Plastik atas pendanaan penelitian ini dan semua personil Pokja DIPA 2013.

\section{DAFTAR PUSTAKA}

Bernal, M. P., Alburquerque, J. A., and Moral, R., 2009. Composting of animal manures and chemical criteria for compost maturity assessment: A review, Bioresource Tech- 
nology, 100(22): 5444-5453.

BSN (Badan Standardisasi Nasional), 2010. SNI 2803:2010 Pupuk NPK padat.

Direktorat Jenderal Perkebunan, 2010. Prospek Komoditas Karet, Direktorat Jenderal Perkebunan, Jakarta.

Haddadin, M. S., Haddadin, J., Arabiyat, O. I., and Hattar, B., 2009. Biological conversion of olive pomace into compost by using Trichoderma harzianum and Phanerochaete chrysosporium, Bioresource technology, 100(20): 4773-4782.

Handayani, M., 2009. Pengaruh dosis pupuk NPK dan kompos terhadap pertumbuhan bibit salam, skripsi, Institut Pertanian Bogor.

Iqbal, M. K., Shafiq, T., Hussain, A., and Ahmed, K., 2010. Effect of enrichment on chemical properties of MSW compost. Bioresource technology, 101(15): 5969-5977.

Kaosol T. and Wandee S., 2009. Cellulolytic Microbial Activator Influence on Decomposition of Rubber Factory Waste Composting, Journal of Environmental Science and Engineering, 4(3): 41-47.

Li, Z., Lu, H., Ren, L., and He, L., 2013. Experimental and modeling approaches for food waste composting: A review. Chemosphere, 93(7): 1247-1257.

Mayer, J., Scheid, S., Widmer, F., Fließbach, A., and Oberholzer, H. R., 2010. How effective are 'Effective microorganisms ${ }^{\circledR}$ (EM)'? Results from a field study in temperate climate, Applied soil ecology, 46(2): 230239.
Menteri Pertanian, 2010. Peraturan Menteri Pertanian No:70/Permentan/SR.140/10/2011 tentang Pupuk Organik.

Raj, D. and Antil, R. S., 2011. Evaluation of maturity and stability parameters of composts prepared from agro-industrial wastes, Bioresource technology, 102(3): 2868-2873.

Ting, A. S. Y., Tay, H., Peh, K. L., Tan, W. S., and Tee, C. S., 2013. Novel isolation of thermophilic Ureibacillus terrenus from compost of empty fruit bunches (EFB) of oil palm and its enzymatic activities, Biocatalysis and Agricultural Biotechnology, 2(2): 162-164.

Mutiara, V. I. dan Hakimi, R., 2012. Potensi pemanfaatan limbah crumb rubber sebagai biomassa di sumatera barat, Simposium Nasional Ekonomi Karet, Fakultas Pertanian Universitas Jambi bekerjasama dengan Perhimpunan Ekonomi Pertanian Indonesia (PERHEPI).

Wei, Z., Zhang, X., Wei, Y., Wen, X., Shi, J., $\mathrm{Wu}$, J., and Xi, B., 2014. Fractions and biodegradability of dissolved organic matter derived from different composts, Bioresource Technology, 161: 179-185.

Xue, D. and Huang, X., 2013. The impact of sewage sludge compost on tree peony growth and soil microbiological, and biochemical properties, Chemosphere, 93(4): 583-589. 
